Original Article

\title{
DIFFERENTIAL SCANNING CALORIMETRY FOR DETERMINING THE THERMODYNAMIC PROPERTIES OF SELECTED HONEYS
}

\author{
Jolanta Tomaszewska-Gras ${ }^{1}$ \\ Sławomir Bakier ${ }^{2 *}$ \\ Kamila Goderska ${ }^{1}$ \\ Krzysztof Mansfeld ${ }^{1}$ \\ 'University of Life Sciences, Wojska Polskiego 31, 60-624 Poznan, Poland \\ 2Bialystok University of Technology, Wiejska 45A, 15-351 Białystok, Poland \\ *corresponding author: s.bakier@pb.edu.pl \\ Received 07 February 2015; accepted 11 May 2015
}

\begin{abstract}
A b s tract
Thermodynamic properties of selected honeys: glass transition temperature ( $\mathrm{Tg})$, the change in specific heat capacity $(\Delta C p)$, and enthalpy $(\Delta \mathrm{H})$ were analysed using differential scanning calorimetry (DSC) in relation to the composition i.e. water and sugar content. Glass transition temperatures $(\mathrm{Tg})$ of various types of honey differed significantly $\left(p<0.05\right.$ ) and ranged from $-49.7^{\circ} \mathrm{C}$ (polyfloral) to $-34.8^{\circ} \mathrm{C}$ (sunflower). There was a strong correlation between the $\mathrm{Tg}$ values and the moisture content in honey $(r=-0.94)$. The degree of crystallisation of the honey also influenced the $\mathrm{Tg}$ values. It has been shown that the presence or absence of sugar crystals influenced the glass transition temperature. For the decrystallised honeys, the $\mathrm{Tg}$ values were 6 to $11^{\circ} \mathrm{C}$ lower than for the crystallised honeys. The more crystallised a honey was, the greater the temperature difference was between the decrystallised and crystallized honey. In conclusion, to obtain reliable DSC results, it is crucial to measure the glass transition after the complete liquefaction of honey.
\end{abstract}

Keywords: differential scanning calorimetry, glass transition, honey.

\section{INTRODUCTION}

Honey is a supersaturated aqueous solution of carbohydrates, containing mainly monosaccharides, glucose, and fructose (Devillers et al., 2004). Honey's chemical composition is supplemented by other sugars (maltose, trehalose, sucrose, melezitose, etc.), organic acids, and slight amounts of such valuable substances as amino acids, enzymes, minerals, and hydroxyacids (Lazaridou et al., 2004; Isidorov et al., 2011; Escuredo et al., 2014). Since glucose is found in the supersaturated state, honey rapidly crystallises during storage (Cavia et al, 2002). Generally consumers prefer honey in the liquid form, thus the technological process includes liquefaction (Assil et al., 1991). This process requires heating of honey to a temperature guaranteeing its complete decrystallisation, as otherwise the honey rapidly recrystallises. However, heating has a negative effect on the properties of honey. Heating reduces the biological activity and promotes the formation of hydroxymethylfurfural (HMF) (Tosi et al., 2002).
For this reason, it is essential to gain insight into the phenomena occurring in honey while the honey is being heated.

Differential scanning calorimetry (DSC) is commonly used to investigate thermal processes occurring in crystallised honey (Lupano, 1997; Venir et al., 2010). This facilitates relatively precise analyses of phenomena occurring during thermal processes, e.g. specific heat determination (Sopade et al., 2006), temperature values at which these processes take place (Mora-Escobedo et al., 2006), and the crystalline fraction share (Al-Habsi et al., 2013). Scanning calorimetry is also used to investigate the process of honey crystallisation (Lupano, 1997; Mora-Escobedo et al., 2006). Using differential scanning calorimetry, it is also possible to identify glass transition occurring at low temperatures. Based on the obtained value of glass transition temperature, it is possible to predict the honey rheological behavior (Lazaridou et al., 2004; Juszczak and Fortuna, 2006), analyse its adulteration (Cordella et al., 2002; 2003), and determine the potential for spray drying (Tonon et 
al., 2009; Samborska and Czelejewska, 2014). Glass transition temperature $(\mathrm{Tg})$ depends on the honey type and water content. Values of $\mathrm{Tg}$ ranges from -42 to $-51^{\circ} \mathrm{C}$ (Kantor et al., 1999; Mora-Escobedo et al., 2006).

In the literature, there is no information about influence of the crystallisation process on the glass transition temperature. The gap of knowledge and data on the thermodynamic properties of honey, was the motivation for this study. Thus, the aim of this study was to investigate basic thermodynamic properties using DSC, particularly to determine specific heat, enthalpy of liquefaction and the glass transition temperature of honeys in the liquid and crystallised state.

\section{MATERIAL AND METHODS}

\section{Samples}

Six raw honey samples were collected by a beekeeper from Northeast Poland and declared as the following honey varieties: rape, coniferous honeydew, heather, polyfloral, lime, and buckwheat. Honey samples were obtained from the honey-combs which had been inserted empty into the hive at the beginning of the bee yield. For the evaluation of the organoleptic features of the collected honey samples, the terms contained in the Polish standard for honey (PN-88/A-77626, 1998) were used. All honey samples revealed organoleptic properties characteristic for the varieties declared by beekeepers. The study also includes a honey sample, which has been obtained from "Sądecki Bartnik" and was declared as sunflower honey (sample 7). According to the producer, declaration sunflower honey came from the Ukraine and its botanical origin was verified using pollen analysis. For all honey samples the measurement of the electrical conductivity (EC) was conducted according to the method described by Bogdanov et al. (1997).

\section{Moisture analysis}

Water content in the honeys was determined by refractometry in accordance with the AOAC method 969.38 (AOAC, 1995). It was performed by measuring the refractive index on an Abbe refractometer at $20^{\circ} \mathrm{C}$, in triplicate. Refractive index values were converted to honey water content using the table developed by Wedmore (1955).

\section{Determination of the sugars}

Sugar content (glucose and fructose) was determined quantitatively and qualitatively by high performance liquid chromatography (HPLC) in compliance with the Jan. 142009 Polish Regulation of the Ministry of Agriculture and Rural Development (Rozporządzenie Ministra Rolnictwa i Rozwoju Wsi z dnia 14.01.2009 r.) based on the methods elaborated by the International Honey Commission (Bogdanov et al., 1997; 2004), applied to obligatory usage in Poland for honey quality assessment. Analyses were done by the HPLC System (Waters, Milford, MA, USA) with a refractometry detector (RI) (Waters, 2414). The sugars were eluted through Carbohydrate Analysis Column (Waters, Milford, MA, USA) with isocratic elution (75\% acetonitryle and $25 \% \mathrm{H}_{2} \mathrm{O}, \mathrm{v} / \mathrm{v}$ ) at an eluent flow rate of $1.5 \mathrm{~mL} / \mathrm{min}$. The temperature of the column and the detector (RI) was $30^{\circ} \mathrm{C}$. The sample volume supplied to the column was $5 \mu \mathrm{L}$. Sugar standards (Sigma-Aldrich, MO, USA) and the external standard method were used for qualitative determination of individual sugars in honey.

\section{Differential scanning calorimetry analysis}

A Perkin Elmer DSC-7 differential scanning calorimeter was used to determine the temperature and enthalpy of honey samples according to the methodology described by Kantor et al. (1999) and modified by the authors. During all the measurements, the thermal analysis system (the head and glove box) was purged by dried nitrogen. The device was calibrated using the standards of indium $\left(T_{m}=156.60^{\circ} \mathrm{C}, \Delta H=28.45 \mathrm{~J} / \mathrm{g}\right.$, Perkin Elmer $)$ and n-dodecane (99.8 purity, $\mathrm{T}_{m}=-9.65^{\circ} \mathrm{C}$, Merck). Next, the samples were weighed in aluminum pans (50 $\mu \mathrm{L}$ total volume, Perkin Elmer) and hermetically sealed. The temperature regime involved the following two steps:

- $1^{\text {st }}$ step: heating cycle - cooling from $25^{\circ} \mathrm{C}$ to $-65^{\circ} \mathrm{C}$ and analysis by heating from $-65^{\circ} \mathrm{C}$ to $100^{\circ} \mathrm{C}$; with a scanning rate of $10^{\circ} \mathrm{C} / \mathrm{min}$.

- $2^{\text {nd }}$ step: heating cycle - re-cooling from $100^{\circ} \mathrm{C}$ to $-65^{\circ} \mathrm{C}$ and analysis by heating from $-65^{\circ} \mathrm{C}$ to $100^{\circ} \mathrm{C}$ with a scanning rate of $10^{\circ} \mathrm{C} / \mathrm{min}$.

The enthalpies $(\Delta \mathrm{H})$ were calculated per $1 \mathrm{~g}$ of honey sample. Glass transition was expressed as a change in specific heat capacity $(\Delta C p)$ and glass transition temperature $\left(T_{g}\right)$, which may be determined using one of the three subsequent values, i.e. onset temperature $\left(\mathrm{Tg}_{0}\right)$, midpoint temperature $\left(\mathrm{T}_{\mathrm{m}}\right)$, and endpoint temperature $\left(\mathrm{Tg}_{\mathrm{e}}\right)$, as shown in Fig. 1. In our research study, the endpoint temperature (Tو for first heating cycle and Tgll for second heating cycle) was taken. 


\section{Statistical analysis}

All measurements were done in triplicate. The results were the average of three independent measurements. The relationship between variables was examined by the linear correlation analysis. The Pearson correlation coefficient $(r)$ and coefficient of determination $\left(r^{2}\right)$ were calculated. To check the significance of differences between means $(p<0.05)$, one-way analysis of variance (ANOVA) and Tukey's test were performed using the software package Statistica 10.0 (Stat soft Inc., Tulsa, OK, USA).

\section{RESULTS}

\section{Composition and properties of the honeys}

The results of composition analyses for the investigated honeys are presented in Table 1. The moisture content ranged between $14.5 \%$ and $18.8 \%$. These values do not exceed the $20 \%$ limit of water content in honey, as established in the Council Directive 2001/110/EC. Table 1 also contains the results of analyses concerning the composition of the main sugars present in honeys, i.e. glucose and fructose. The determined content of those sugars was higher than $60 \%$, which is also in agreement with the limits (>60) established in the Council Directive 2001/110/EC. The highest concentration of glucose was found to be in sunflower honey (39.49\%) and the lowest $30.30 \%$ in lime, buckwheat, and honeydew honey. The concentration of fructose ranged from 31.18\% (sunflower honey) to 35.05\% (buckwheat honey). In turn, the highest concentration of total fructose and glucose content (73.31\%) was recorded in polyfloral honey. The electrical conductivity values were below $0.4 \mathrm{mS} / \mathrm{cm}$, only in the case of honeydew which was $1.13 \mathrm{mS} / \mathrm{cm}$.

\section{Thermodynamic properties}

Figure 2 presents a typical DSC thermogram obtained after heating $\left(-60\right.$ to $\left.220^{\circ} \mathrm{C}\right)$ polyfloral nectar, crystallised honey. For the honeys heated in the solid or semi-solid states, three thermal phenomena may be observed, as is shown in Figure 2. The first one is glass transition, connected with a change in

Moisture content and sugar composition (\%) of selected Polish honeys

\begin{tabular}{|c|c|c|c|c|c|c|}
\hline \multirow{2}{*}{$\begin{array}{l}\text { Honey } \\
\text { type }\end{array}$} & \multirow{2}{*}{$\begin{array}{c}\text { Water content } \\
(\%)\end{array}$} & \multicolumn{2}{|c|}{ Sugar content (\%) } & \multirow{2}{*}{$\begin{array}{c}\text { Total simple } \\
\text { sugars (\%) }\end{array}$} & \multirow{2}{*}{$\begin{array}{c}\text { Glucose / } \\
\text { water ratio }\end{array}$} & \multirow{2}{*}{$\begin{array}{c}\text { Fructose / } \\
\text { glucose ratio } \\
\text { F/G }\end{array}$} \\
\hline & & Glucose & Fructose* & & & \\
\hline Polyfloral & $18.80 \pm 0.17^{a}$ & $38.26 \pm 3.17^{a}$ & $35.04 \pm 1.45$ & $73.31^{b}$ & $2.04^{\mathrm{bc}}$ & $0.92^{\mathrm{c}}$ \\
\hline Heather & $18.60 \pm 0.00^{\mathrm{a}}$ & $31.00 \pm 1.46^{\mathrm{bc}}$ & $35.10 \pm 1.75$ & $66.10^{\mathrm{ab}}$ & $1.67^{\mathrm{d}}$ & $1.13^{a}$ \\
\hline Rape & $17.53 \pm 0.23^{b}$ & $36.15 \pm 0.31^{\mathrm{ab}}$ & $34.16 \pm 0.58$ & $70.30^{\mathrm{ab}}$ & $2.06^{b}$ & $0.94^{\mathrm{bc}}$ \\
\hline Lime & $17.51 \pm 0.06^{b}$ & $30.30 \pm 0.57^{c}$ & $31.42 \pm 0.79$ & $61.72^{b}$ & $1.73^{\mathrm{cd}}$ & $1.04^{\mathrm{b}}$ \\
\hline Buckwheat & $17.50 \pm 0.06^{b}$ & $30.96 \pm 2.06^{b c}$ & $35.05 \pm 1.13$ & $66.01^{\mathrm{ab}}$ & $1.77^{\mathrm{bcd}}$ & $1.13^{a}$ \\
\hline Honeydew & $16.82 \pm 0.18^{c}$ & $30.03 \pm 2.90^{c}$ & $33.09 \pm 2.57$ & $63.12^{b}$ & $1.78^{\text {bcd }}$ & $1.10^{a}$ \\
\hline Sunflower & $14.53 \pm 0.23^{d}$ & $39.49 \pm 0.85^{a}$ & $31.18 \pm 0.90$ & $70.67^{\mathrm{ab}}$ & $2.72^{a}$ & $0.79^{d}$ \\
\hline
\end{tabular}

*in the case of fructose no significantly differences between various types of honeys were obtained.

Values are expressed as mean \pm standard deviation for three replications.

Values with the same letters in the same raw are not significantly different at the $p<0.05$.

Table 2.

Thermodynamic properties of selected Polish honeys

\begin{tabular}{cccccc}
\hline \multirow{2}{*}{$\begin{array}{c}\text { Honey } \\
\text { type }\end{array}$} & \multicolumn{3}{c}{$\begin{array}{c}\text { First heating cycle } \\
\text { of crystallized honey }\end{array}$} & $\begin{array}{c}\text { Second heating cycle after } \\
\text { decrystallization }\end{array}$ \\
\cline { 2 - 6 } & $\begin{array}{c}\text { Glass transition } \\
\text { temperature } \\
\left.\text { Tgl }{ }^{\circ} \mathrm{C}\right)\end{array}$ & $\begin{array}{c}\text { Solution } \\
\text { enthalpy } \Delta \mathrm{H} \\
(\mathrm{J} / \mathrm{g})\end{array}$ & $\begin{array}{c}\text { Peak temperature } \\
\text { Tp }\left({ }^{\circ} \mathrm{C}\right)\end{array}$ & $\begin{array}{c}\text { Class transition } \\
\text { temperature } \\
\text { Tgll }\left({ }^{\circ} \mathrm{C}\right)\end{array}$ & $\begin{array}{c}\text { Specific heat } \\
\text { capacity } \\
\Delta \mathrm{Cp}\left(\mathrm{J} / \mathrm{g}^{\circ} \mathrm{C}\right)\end{array}$ \\
\hline Polyfloral & $-55.71 \pm 0.44^{\mathrm{d}}$ & $34.79 \pm 1.48^{\mathrm{b}}$ & $53.98 \pm 0.29^{\mathrm{c}}$ & $-49.67 \pm 0.60^{\mathrm{f}}$ & $0.62 \pm 0.03^{\mathrm{ab}}$ \\
\hline Heather & $-51.85 \pm 0.68^{\mathrm{c}}$ & $27.45 \pm 1.80^{\mathrm{c}}$ & $49.69 \pm 0.68^{\mathrm{e}}$ & $-47.35 \pm 0.20^{\mathrm{e}}$ & $0.60 \pm 0.02^{\mathrm{ab}}$ \\
\hline Rape & $-52.79 \pm 1.07^{\mathrm{c}}$ & $37.82 \pm 1.57^{\mathrm{b}}$ & $55.94 \pm 0.26^{\mathrm{b}}$ & $-45.89 \pm 1.08^{\mathrm{cd}}$ & $0.63 \pm 0.05^{\mathrm{b}}$ \\
\hline Lime & $-51.16 \pm 0.65^{\mathrm{c}}$ & $28.35 \pm 2.00^{\mathrm{c}}$ & $47.28 \pm 0.31^{\mathrm{f}}$ & $-46.67 \pm 0.30^{\mathrm{de}}$ & $0.61 \pm 0.03^{\mathrm{ab}}$ \\
\hline Buckwheat & $-46.89 \pm 0.23^{\mathrm{b}}$ & $15.90 \pm 0.36^{\mathrm{d}}$ & $51.97 \pm 0.68^{\mathrm{d}}$ & $-44.95 \pm 0.10^{\mathrm{c}}$ & $0.57 \pm 0.03^{\mathrm{b}}$ \\
\hline Honeydew & $-46.26 \pm 0.65^{\mathrm{b}}$ & $26.51 \pm 1.53^{\mathrm{c}}$ & $49.05 \pm 0.55^{\mathrm{e}}$ & $-42.37 \pm 0.18^{\mathrm{b}}$ & $0.65 \pm 0.02^{\mathrm{ab}}$ \\
\hline Sunflower & $-44.09 \pm 0.73^{\mathrm{a}}$ & $60.02 \pm 3.24^{\mathrm{a}}$ & $65.76 \pm 0.18^{\mathrm{a}}$ & $-34.78 \pm 0.42^{\mathrm{a}}$ & $0.70 \pm 0.06^{\mathrm{a}}$ \\
\hline
\end{tabular}

Values are expressed as mean \pm standard deviation for three replications.

Values with the same letters in the same raw are not significantly different at the $p<0.05$. 


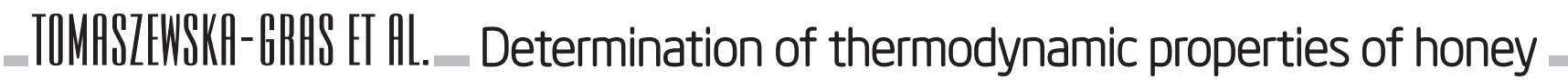

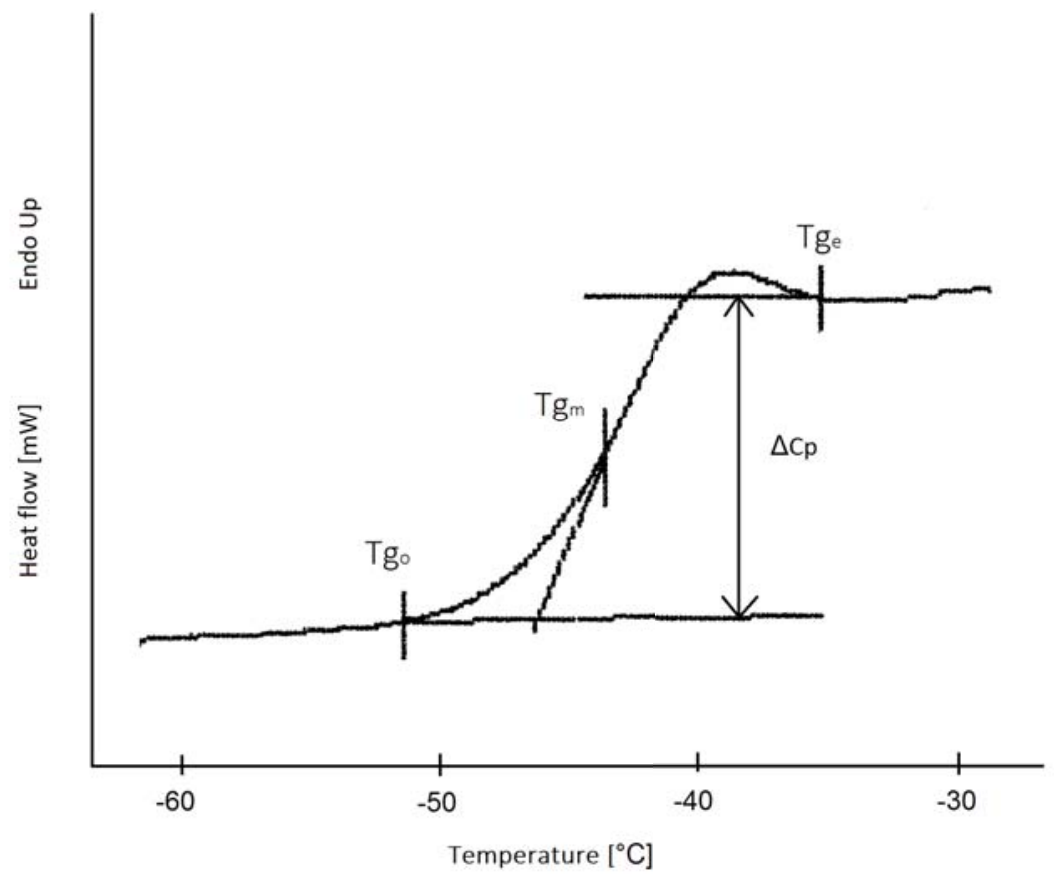

Fig. 1. Determination of glass transition temperatures by differential scanning calorimetry (DSC): onset temperature $\left(\mathrm{Tg}_{0}\right)$, midpoint temperature $\left(\mathrm{T}_{\mathrm{m}}\right)$, and endpoint temperature $\left(\mathrm{Tg}_{\mathrm{e}}\right)$, and change in specific heat capacity $(\Delta C p)$.

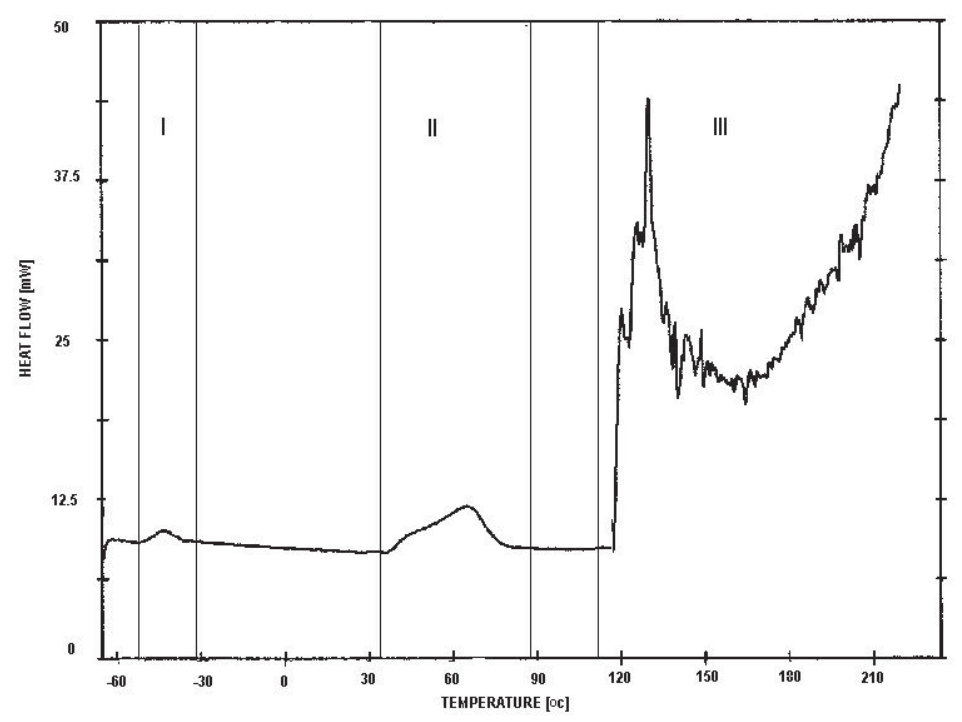

Fig. 2. Differential scanning calorimetry (DSC) heating thermogram of polyfloral honey in the crystallised state in the range of temperatures from $-65^{\circ} \mathrm{C}$ to $220^{\circ} \mathrm{C}$; heating rate $10^{\circ} \mathrm{C} / \mathrm{min}$.

heat capacity and occurring at a temperature range between -60 and $-40^{\circ} \mathrm{C}$. This transition occurs when the material changes upon cooling from the rubberylike state into the hard, glassy state or conversely from the glassy solid to rubbery state upon heating. The second thermal phenomenon is connected with the transition from the solid to the liquid state. Due to the change of the water state in the crystals, the decrystallisation phenomenon occurs when sugar crystals dissolve. This transition takes place only in the case of honeys found in a partly or completely crystallised state, but it disappears after regular cooling and heating. The characteristic features of the transition include such parameters as peak temperature (Tp) and solution enthalpy $(\Delta \mathrm{H})$. The value of $\Delta \mathrm{H}$ is proportional to the contents of the crystallised fraction in honey. The third most intensive transition, visible in Figure 2 as a very extensive peak, takes place in the range of temperatures from approximately $110-140$ to $220^{\circ} \mathrm{C}$. This transition is caused by the process of sugars melting and caramelisation. In further studies concerning the thermo- 


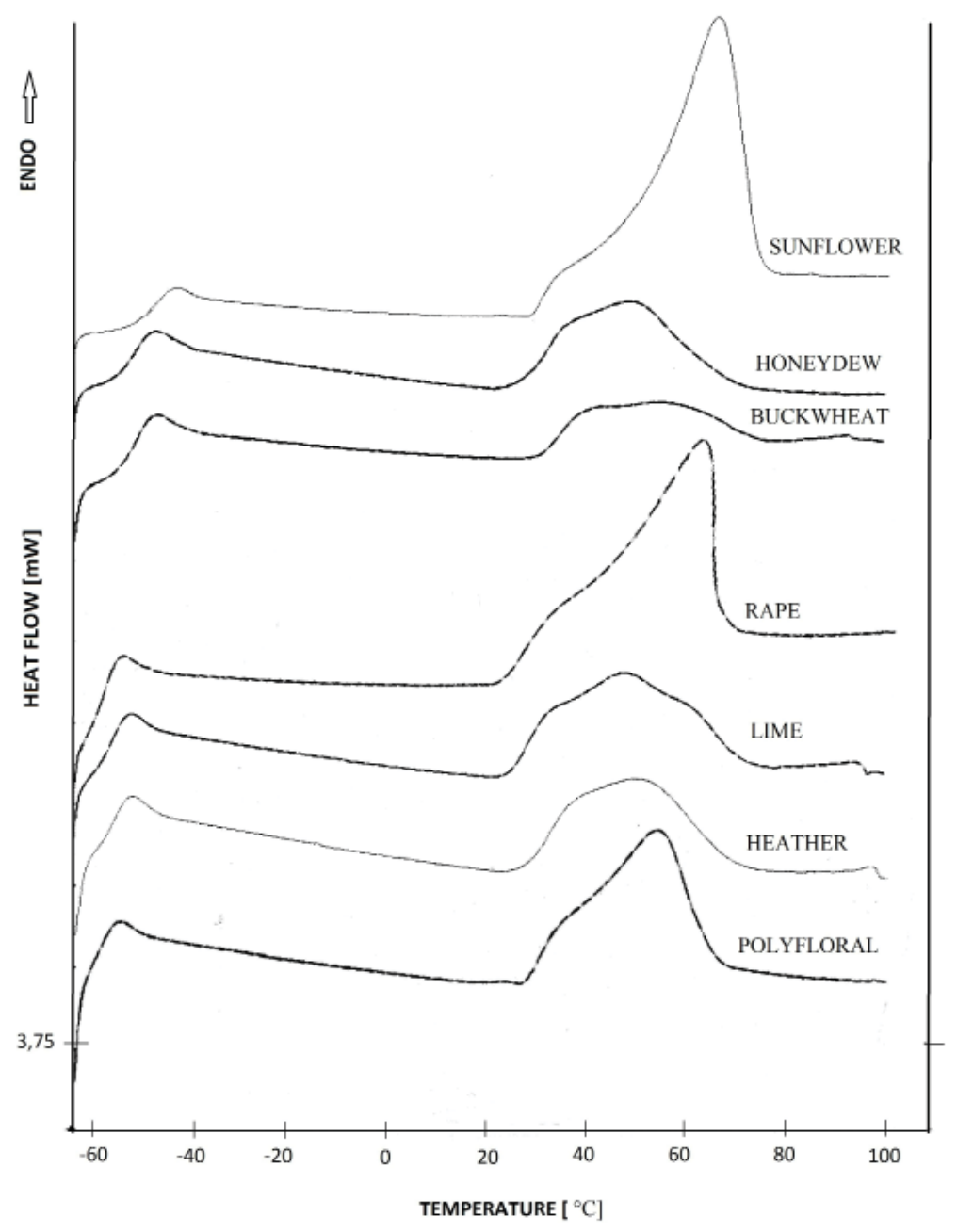

Fig. 3. Differential scanning calorimetry (DSC) heating thermograms of various honeys - $1^{\text {st }}$ heating cycle in the range of temperatures from $-65^{\circ} \mathrm{C}$ to $100^{\circ} \mathrm{C}$; heating rate $10^{\circ} \mathrm{C} / \mathrm{min}$.

dynamic properties of various types of honeys, only the first two thermal phenomena; glass transition and solute - solution transition, were investigated. The analyses were conducted in two heating cycles. After the first cycle, two transitions were observed (glass transition and solute - solution transition). Whereas in the second heating cycle, after the decrystallisation, only the glass transition could be observed.

Figure 3 presents DSC heating curves acquired as a result of the firstheating of various types of honeys, in which the honeys were partly or completely crystallised, and where the honeys had been previously cooled to a temperature of $-65^{\circ} \mathrm{C}$. For each of the honeys, two thermal phenomena were observed during heating, i.e. glass transition and dissolution of sugar crystals. Glass transition temperatures, given in Table 2 as the endpoint temperatures (Tواو), ranged from $-55.71^{\circ} \mathrm{C}$ for polyfloral honey to $-44.09^{\circ} \mathrm{C}$ for sunflower honey. The second transition, shown in
Figure 3 (a broad and clear peak), is related to the solute-solution transition, which takes place in the range of from $47.28^{\circ} \mathrm{C}$ in lime honey to $65.76^{\circ} \mathrm{C}$ in sunflower honey (Tab. 2). Between individual honey types, significant differences may be observed in the values of enthalpy $(\Delta \mathrm{H})$, which are connected with differences in the degree of crystallisation. The highest value of enthalpy was recorded for sunflower honey $(60.02 \mathrm{~J} / \mathrm{g})$, which was the hardest and most crystallised honey, and the lowest for buckwheat honey $(15.9 \mathrm{~J} / \mathrm{g})$. It needs to be stressed, that for four of the tested honeys, i.e. sunflower, polyfloral, rape, and buckwheat, the honey peak temperature was higher than $50^{\circ} \mathrm{C}$. Such a high temperature is what is most frequently used for the liquefaction of honey in the methods applied in thermal analyses of honeys (Lazaridou et al., 2004). As the above results show, this practice does not guarantee complete decrystallisation. 


\section{_TOMASIEWSKA-GHAS ET fll._- Determination of thermodynamic properties of honey.}

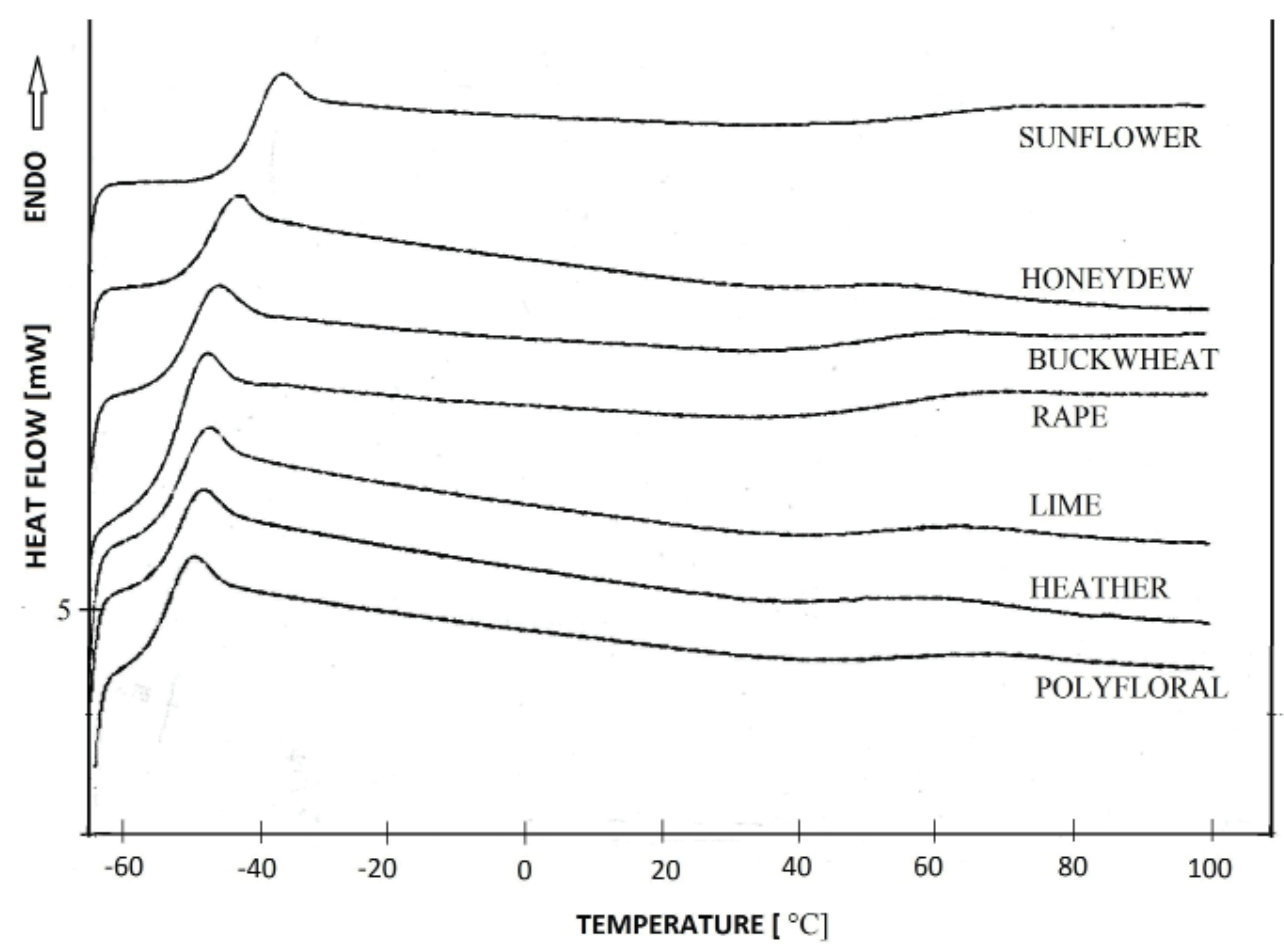

Fig. 4. Differential scanning calorimetry (DSC) heating thermograms of various honeys - $2^{\text {nd }}$ heating cycle after decrystallisation in the range of temperatures from $-65^{\circ} \mathrm{C}$ to $100^{\circ} \mathrm{C}$; heating rate $10^{\circ} \mathrm{C} / \mathrm{min}$.

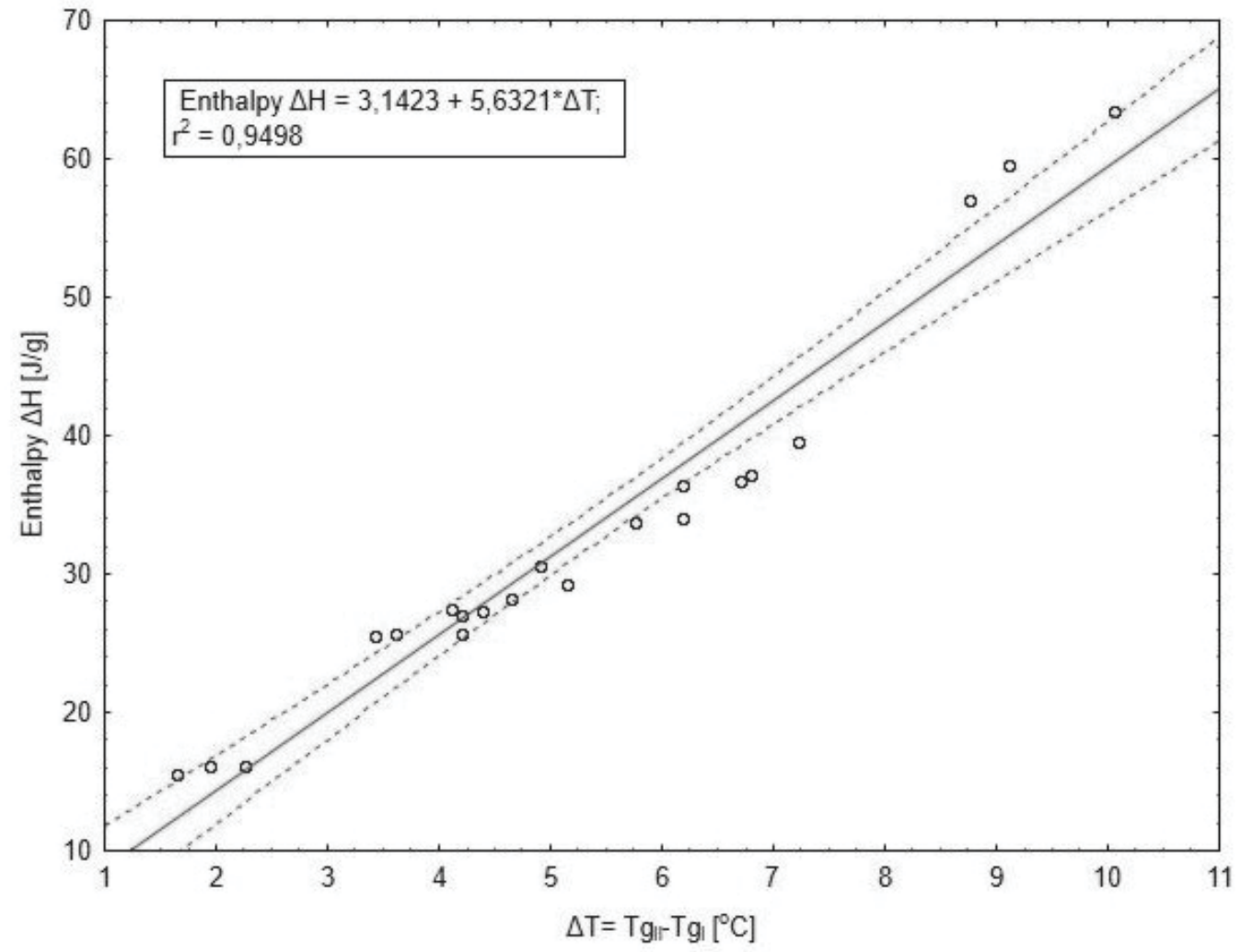

Fig. 5. Relationship between enthalpy $(\Delta \mathrm{H})$ and difference in glass transition temperatures between $1^{\text {st }}$ and $2^{\text {nd }}$ cycle of heating $(\Delta T=T g l l-T g)$. Tgl and Tgll - glass transition temperatures I and II. 


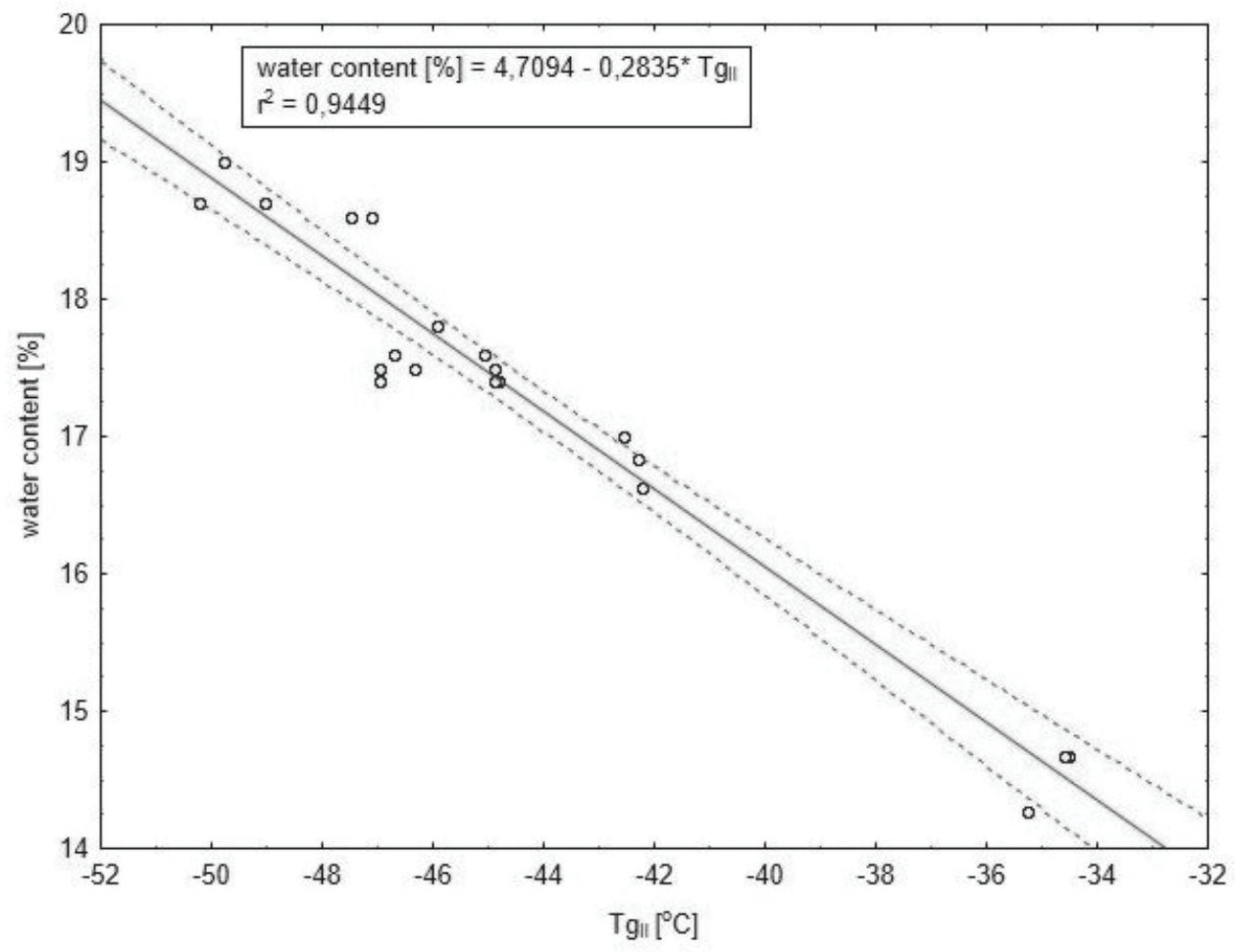

Fig. 6. Relationship between glass transition temperature (Tgll) and water content in honey.

In Figure 4, the second cycle heating DSC curves are presented. These curves were obtained after the decrystallisation of honeys. The DSC curves show the heating process from $-65^{\circ} \mathrm{C}$ to $100^{\circ} \mathrm{C}$, and only one characteristic phenomenon can be observed, i.e. glass transition. No second transition related to solution enthalpy can be found. This indicates the decrystallisation process was complete and all sugar crystals were dissolved. The phenomenon of glass transition occurred in the temperature range of from $-49.67^{\circ} \mathrm{C}$ (polyfloral) to $-34.78^{\circ} \mathrm{C}$ (sunflower). The differences between glass transition temperatures (Tgll) of various honey, shown in Table 2, were statistically significant $(p<0.05)$. Table 2 also presents the results for $\Delta C p$ changes in each of the honey types. The values of these honey types differed significantly only for sunflower and buckwheat honeys $(p<0.05)$, while for the other honeys, the differences were not statistically significant.

Comparing glass transition temperatures after a first and second heating show that some differences in $\mathrm{Tg}$ temperatures can be seen, i.e. after a second heating the $\mathrm{Tg}$ temperatures are lower for each type of honey. These differences between glass transition temperatures ( $\Delta T=T g l l-T g l)$ were not equal, as can be seen in Figure 5 . This phenomenon indicates that complete decrystallisation (a lack of the sugar crystals) results in a shift of glass transition temperatures towards higher values, while the presence of the crystalline structure in honey reduces the glass transition temperature. The more crystallised a given honey was, the greater was the difference between the determined temperatures for crystallised and decrystallised honey (Tgll - Tgl) (Fig. 5). A close relationship was found ( $r=0.9498)$ between the difference in $\mathrm{Tg}$ temperatures $(\Delta \mathrm{T})$ and solution enthalpy $(\Delta \mathrm{H})$.

Despite the fact that after a second heating all the honeys were fully liquefied, the temperature values (Tgll) still differed between various honeys. As it can be seen in Table 2, these differences, were statistically significant $(p<0.05)$ and they arose from various contents of water in the honey. The close relationship between Tgll temperature and the water content is shown in Figure 6. Significant linear correlation with a high correlation coefficient ( $r=-0.9449$ ) was obtained. It should be noted, that honey with the lowest temperature Tgll (polyfloral honey) has the highest water content, while the sunflower honey had the lowest water content and the highest temperature Tgll. 


\section{DISCUSSION}

A composition analysis of all the investigated honeys was carried out as the first step of this research study. The analysis revealed that the water and sugar contents were in agreement with the limits established in the Council Directive 2001/110/EC. For most of the honeys, the water and glucose content as well as the $F / G$ ratio and glucose to water ratio, were in the range presented by Persano Oddo and Piro (2004). In the case of sunflower honey, the results were different from those obtained by Persano Oddo and Piro (2004), and Yardibi and Gumus (2010), who found a slightly higher water content in this type of honey. They found the water content to be between 14.9 and $20.1 \%$, and the fructose to glucose $(F / G)$ ratio to be between 0.95 and 1.42 .

Our study focused on the analysis of the thermodynamic properties of honeys. Using differential scanning calorimetry (DSC) glass transition, i.e. temperature and change of heat capacity, the $\Delta C p$ and solute - solution transition of the selected honeys were investigated. Taking into account recent publications on the glass transition temperature as a useful parameter for the authenticity of honey, various aspects of $\mathrm{Tg}$ temperature determination were analysed (Escuredo et al., 2014). The analyses of the thermodynamic properties were conducted in two heating cycles. After the first heating, it was found that a temperature of $50^{\circ} \mathrm{C}$, which is most frequently used for liquefaction of honey, does not guarantee the complete decrystallisation of honey. When comparing the results of glass transition determination after the first and second heating, some differences were observed. It was apparent that these differences were from an incomplete liquefaction of the honey. This indicates that the presence of the crystalline structure in honey affects the glass transition temperature. The indication is also that for DSC analysis it is very important to carry out this determination on completely decrystallised honey which has no sugar crystals. Differential scanning calorimetry heating analysis of $\mathrm{Tg}$ temperature should be done after checking to make sure the honeys are completely decrystallised. If endothermic solute-soIution transition on the thermogram is visible, then it is clear there are still sugar crystals.

In addition, it was observed that glass transition temperatures (Tgll) differed significantly for various types of honeys. It was found that the Tgll were similar to those obtained by Lazaridou et al. (2004) and Oroian et al. (2013), where the Tg point of honeydew $\left(-40.52^{\circ} \mathrm{C}\right)$ and polyfloral $\left(-47.4^{\circ} \mathrm{C}\right)$ were analysed. The differences between Tgll values for various honeys were affected by different water content, confirmed by the high correlation coefficient ( $r=-0.9449)$. This is in agreement with Kantor et al. (1999), where the effect of moisture content on glass transition temperature was shown. Due to the plasticisation effect of water, Tg values shifted to lower temperatures with an increase in the moisture content. Slade and Levine (1991) indicated that glass transition temperature is a function of not only moisture content, but also of the type of solute. In this case, the relationships between Tgll and sugar contents were not statistically significant.

\section{CONCLUSIS}

Glass transition temperatures are strongly dependent on the moisture content in honey and these temperatures decreased with increasing water content. It was also found, that the degree of honey crystallisation, and thus presence or absence of sugar crystals, influences the glass transition temperature. The more crystallised a given honey was, the greater the difference between determined temperatures for crystallised and decrystallised (TgllTواg). Therefore, it is crucial that for reliable DSC determination, honeys should be tested for complete decrystallisation before the measurement of the glass transition point. Too low of a temperature in the decrystalliation process may cause incomplete dissolution of the crystallised phase and incorrect values determined for the $\mathrm{Tg}$. Too high of a temperature will lead to sugar caramelisation. The above practices are necessary pre-conditions for obtaining repeatable results of the glass transition analyses in honeys.

\section{REFERENCES}

Al-Habsi N. A., Davis F. J., Niranjan K. (2013) Determine Crystalline Glucose Content of Honey Based on DSC, HPLC, and Viscosity Measurements, and Their Use to Examine the Setting Propensity of Honey. Journal of Food Science 78(6): 845-852.

AOAC (1995) Official Methods of Analysis, 15th edn. Association of Official Analytical Chemists. Washington, DC.

Assil H. I., Sterling R., Sporns P. (1991) Crystal control in processed liquid honey. Journal of Food Science 56: 1034-1037. 


\section{J. APRC. SCLI. VOL. 59 NO. 12015}

Bogdanov S., Ruoff K., Persano Oddo L. (2004) Physicochemical methods for the characterization of unifloral honeys: a review. Apidologie 35: 4-17.

Bogdanov S., Martin P., Lüllmann C., Borneck R., Flamini C. Morlot M., Heretier J., Vorwohl G., Russmann H., PersanoOddo L., Sabatini A. G., Marcazzan G. L., Marioleas P., Tsigouri K., Kerkvliet J., Ortiz A., Ivanov T. (1 997) Harmonised methods of the European Honey Commission. Apidologie, extra issue: 1 -59.

Cavia M. M., Fernández-Muiño M. A., Gömez-Alonso E., Montes-Pérez M. J., Huidobro J. F., Sancho M. T. (2002) Evolution of fructose and glucose in honey over one year, influence of induced granulation. Food Chemistry 78: 157-161.

Cordella C., Faucon J. P., Cabrol-Bass D., Sbirrazzuoli N. (2003) Application of DSC as a tool for honey floral species characterization and adulteration detection. Journal of Thermal Analysis and Calorimetry 71: 279-290.

Cordella C., Antinelli I. F, Aurieres C., Faucon I. P, CabrolBass D., Sbirrazzuoli N. (2002) Use of Differential Scanning Calorimetry (DSC) as a New Technique for Detection of Adulteration in Honeys. 1. Study of Adulteration Effect on Honey Thermal Behavior. Journal of Agricultural and Food Chemistry 50: 203-208.

Council Directive 2001/1 10/EC of 20 December 2001 relating to honey. Official Journal of the European Communities L 10: 47-52.

Devillers J., Morlot M., Pham-Delčgue M. H., Doré J. C. (2004) Classification of monofloral honeys based on their quality control data. Food Chemistry 86: 305-312.

Escuredo O., Dobre I., Fernández-González M. M., Seijo C. (2014) Contribution of botanical origin and sugar composition of honeys on the crystallization phenomenon. Food Chemistry 149: 84-90.

Isidorov V. A, Czyżewska U., Jankowska E., Bakier S. (2011) Determination of royal jelly acids in honey. Food Chemistry 124: 387-391.

Juszczak L., Fortuna T. (2006) Rheology of selected Polish honeys. Journal of Food Engineering 75: 43-49.

Kantor Z., Pitsi G., Thoen J. (1999) Glass transition temperature of honey as function of water content as determined by differential scanning calorimetry. Journal of Agricultural and Food Chemistry 47: 2327-2330.
Lazaridou A., Biliaderis C. G., Bacandritsos N., Sabatini A. G. (2004) Composition, thermal and rheological behavior of selected Greek honeys. Journal of Food Engineering 64: 9-21

Lupano C. E. (1997) DSC study of honey granulation stored at various temperatures. Food Research International 30(9): 683-688.

Mora-Escobedo R., Moguel-Ordóňez Y., Jarmillo-Flores M. E., Gutiérrez-López G. F. (2006) The composition, rheological and thermal properties of tajonal (Viguiera denata) mexican honey. International Journal Food Properties 9: 299-316.

Oroian M., Amariei S., Escriche I., Gutt G. (2013) Rheological aspects of Spanish honeys. Food and Bioprocess Technology 6: 228-241.

Persano Oddo L., Piro R. (2004) Main European unifloral honeys: descriptive sheets. Apidologie 35: S38-S81.

PN-88/A-77626 (1998) "Miód pszczeli". Dziennik Norm i Miar nr 8. Wydawnictwo Normalizacyjne Alfa.

Rozporządzenie Ministra Rolnictwa i Rozwoju Wsi z dnia 14.01.2009 r. w sprawie metod związanych z dokonaniem oceny miodu. Dz. U. Nr 17 poz. 94.

Samborska K., Czelejewska M. (2014) the influence of thermal treatment and spray drying on the physicochemical properties of polish honeys. Journal of Food Processing and Preservation 38: 413-419.

Slade L., Levine H. (1991) Beyond water activity: Recent advances based on an alternative approach to the assessment of food quality and safety. Critical Reviews in Food Science and Nutrition 30: 1 15-360.

Sopade P. A., Halley P. J., D’Arcy B. R. (2006) Specific heat capacity of Australian honeys from 35 to 165c as a function of composition using differential scanning calorimetry. Journal of Food Processing and Preservation 30: 99-109.

Statistica 10.0. Stat soft Inc. Tulsa, OK, USA.

Tonon R. V., Baroni A. F., Brabet C., Gibert O., Pallet D., Hubinger M. D. (2009) Water sorption and glass transition temperature of spray dried açai (Euterpe oleracea Mart.) juice. Journal of Food Engineering 94: 215-221. 


\section{_IOMASIEWSKR-GPHAS ET HL.__Determination of thermodynamic properties of honey}

Tosi E., Ciappini M., Lucero H., Re’ E. (2002) Honey thermal treatment effects on hydroxymethylfurfural content. Food Chemistry 77: 71-74.

Venir E., Spaziani M., Maltini E. (2010) Crystallization in "Tarassaco" Italian honey studied by DSC. Food Chemistry 122: 410-415.
Wedmore E. B. (1955) The accurate determination of the water content of honeys I. Introduction and results. Bee Word 36(1 1): 197-206.

Yardibi M. F., Gumus T. (2010) Some physico-chemical characteristics of honeys produced from sunflower plant (Helianthus annuus L.). International Journal of Food Science and Technology 45: 707-712. 